\title{
Aldosterone mediates angiotensin II-stimulated rat vascular smooth muscle cell proliferation
}

\author{
F Xiao, J R Puddefoot and G P Vinson
}

Molecular and Cellular Biology, Division of Biomedical Sciences, Queen Mary and Westfield College, University of London, London E1 4NS, UK

(Requests for offprints should be addressed to G P Vinson; Email: G.P.Vinson@qmw.ac.uk)

\begin{abstract}
Aldosterone, possibly locally generated, has been suggested to have a role in potentiating angiotensin II (AII)-stimulated hypertrophy of cultured vascular smooth muscle cells. To examine the possibility that aldosterone may mediate the proliferative actions of AII, rat aortic smooth muscle cells (RASMCs) in culture were treated with AII in the presence and absence of the specific AII type 1 receptor (AT1) antagonist, losartan, and aldosterone was assayed in culture medium extracts by radioimmunoassay. AII significantly enhanced aldosterone formation (at $10^{-8} \mathrm{M}: 123 \cdot 8 \pm 14 \cdot 85$ vs control $71 \cdot 28 \pm$ $8 \cdot 71 \mathrm{fmol} / 10^{5}$ cells, $P<0 \cdot 05$; at $10^{-7} \mathrm{M}: 172 \cdot 38 \pm 33 \cdot 44$, $P<0 \cdot 05$ ), but not in the presence of losartan (at $10^{-8} \mathrm{M}$ : $53.71 \pm 18.73, \quad P>0.05 ; \quad$ at $10^{-7} \mathrm{M}: \quad 89 \cdot 68 \pm 25 \cdot 05$, $P>0 \cdot 05)$. In other studies, the reverse transcriptase-
\end{abstract}

polymerase chain reaction, performed on RNA extracted from RASMCs using aldosterone synthase (CYP11B2) specific primers, gave a single band of about $268 \mathrm{bp}$, consistent with that expected for the enzyme. Finally, using $\left[{ }^{3} \mathrm{H}\right]$ methylthymidine uptake as an index of cellular proliferation, tritium incorporation was increased in the AII-treated group at concentrations greater than $10^{-10} \mathrm{M}$. The aldosterone antagonist, spironolactone $\left(10^{-5} \mathrm{M}\right)$, inhibited the incorporation of $\left[{ }^{3} \mathrm{H}\right]$ thymidine into RASMCs stimulated by AII.

These results suggest that locally generated aldosterone may mediate the effects of AII, acting via the AT1 receptor, in stimulating RASMC proliferation.

Journal of Endocrinology (2000) 165, 533-536

\section{Introduction}

Aldosterone is crucial for fluid, electrolyte, and blood pressure homeostasis in vertebrates (Gomez-Sanchez et al. 1997). In mammals, it is synthesized in the zona glomerulosa of the adrenal cortex, and its target organs are known to include epithelia involved in the vectorial transfer of sodium, vascular smooth muscle cells, and specific areas of the brain (Gomez-Sanchez 1991). Angiotensin II (AII) is an important regulator of adrenal mineralocorticoid biosynthesis and secretion (Shibata et al. 1991, Clyne et al. 1996), and it maintains both the structure of the glomerulosa, and the secretion of aldosterone (Aguilera \& Catt 1983, Natarajan et al. 1992, McEwan et al. 1996). It also increases the levels of aldosterone synthase in glomerulosa cells, thus replicating the actions of a low sodium diet (Aguilera et al. 1980, Ogishima et al. 1992, Rubattu et al. 1994).

As well as this classical steroid biosynthetic pathway in the adrenal, extra-adrenal sites of steroid hormone production have been identified, for example in brain and blood vessels (Casey \& MacDonald 1982, Mellon \& Deschepper 1993, Hatakeyama et al. 1994, Takeda et al. 1996). Aldosterone synthase and 11ß-hydroxylase gene expression have been demonstrated in rat mesenteric artery, and also in endothelial and smooth muscle cells isolated from human pulmonary artery (Hatekeyama et al. 1994, 1996, Takeda et al. 1995, 1996). Hatakeyama et al. (1994) also showed that externally added aldosterone potentiates AIIinduced hypertrophy of cultured human vascular smooth muscle cells, suggesting a physiological role for the steroid. The present study was designed to determine if AIIstimulated vascular smooth muscle cell proliferation may be regulated via local aldosterone production.

\section{Materials and Methods}

Preparation of rat aortic smooth muscle cells (RASMCs)

RASMCs were isolated from rat thoracic and abdominal arteries by the media explant method, and were cultured over several passages according to the method of Ross (1971) with minor modifications. Cells were incubated with RPMI-1640 culture medium (Sigma, Poole, Dorset, UK) containing 100 units/ml penicillin (Gibco, Paisley, Strathclyde, UK), $100 \mu \mathrm{g} / \mathrm{ml}$ streptomycin (Gibco), $4 \mu \mathrm{mol} / 1 \mathrm{~L}$-glutamine (Gibco) and 20\% fetal bovine serum (FBS, Sigma). Cells growing from the explants became relatively confluent within a period of approximately 2 weeks. They were then rinsed with phosphate buffered 
saline (PBS, Sigma) and subsequently trypsinized with a solution of $0 \cdot 125 \%$ trypsin and $0.02 \%$ EDTA in PBS by incubating them in this solution for $1-2 \mathrm{~min}$ at $37^{\circ} \mathrm{C}$. The resulting cell suspension was pipetted into $75-\mathrm{cm}^{2}$ tissue culture flasks containing $10 \mathrm{ml}$ culture medium and incubated as previously described. Experiments were performed using cells from passages 3-5.

\section{Aldosterone assay}

One millilitre aliquots of an RASMC suspension $\left(10^{5}\right.$ cells $/ \mathrm{ml}$ ) in RPMI-1640 supplemented with 20\% FBS were distributed to a 24-well multiwell plate on the first day of the experiment. The medium was replaced $24 \mathrm{~h}$ after subculture with serum-free medium (SFM) containing $10^{-10}, 10^{-9}, 10^{-8}, 10^{-7}$ and $10^{-6} \mathrm{M}$ AII with or without the specific AII type 1 receptor antagonist, losartan $\left(10^{-5} \mathrm{M}\right.$, generously given by Merck, Hoddesdon, UK); there were 4 wells per group and experiments were terminated after $48 \mathrm{~h}$. Media were extracted with ethyl acetate, and aldosterone was assayed by RIA, using methods previously described (Henville et al. 1989).

\section{Tritiated thymidine uptake}

A suspension of RASMCs was distributed to a multiwell plate, cultured and stimulated as for the aldosterone assay experiment above. After $24 \mathrm{~h}$ culture, when the cells were quiescent, the medium was replaced, and fresh medium containing angiotensin II and the aldosterone antagonist, spironolactone, was added as required. After a further $24 \mathrm{~h},\left[{ }^{3} \mathrm{H}\right]$ methylthymidine $(10 \mu \mathrm{l}, 0 \cdot 1 \mathrm{mCi} / \mathrm{ml}$, Amersham, Little Chalfont, Bucks, UK) was added to each well. The cells were collected using the method of Oikawa et al. (1987), $24 \mathrm{~h}$ after the addition of radioactive thymidine. Media were aspirated and the cultured cells were rinsed 3 times with cold PBS. Cells were then dissolved in $0.5 \mathrm{ml} 0.1 \mathrm{M} \mathrm{NaOH}$ and a $0.3 \mathrm{ml}$ aliquot was mixed with $3.5 \mathrm{ml}$ scintillation fluid (Packard, Pangbourne, Berks, UK) and, after standing overnight at room temperature, tritium content was assayed in a WALLAC 1410 (Perkinelmer, Cambridge, UK) liquid scintillation counter.

\section{Isolation of total cellular RNA and reverse transcriptase-polymerase chain reaction ( $R T-P C R$ )}

Total cellular RNA was extracted from cultured RASMCs using the RNAce Total Pure kit (Bioline, London, UK) according to the manufacturer's protocol, and quantified spectrophotometrically by measuring absorbancy at 260 and $280 \mathrm{~nm}$. The extracted RNA was treated with DNAase (Promega, Southampton, UK) as described in the manufacturer's protocol.

RNA was reverse-transcribed as follows. A $20 \mu \mathrm{l}$ reaction volume was used containing the following components: $5 \mu \mathrm{g}$ DNAse-treated total RNA, $4 \mu \mathrm{l} 5 \times$ First

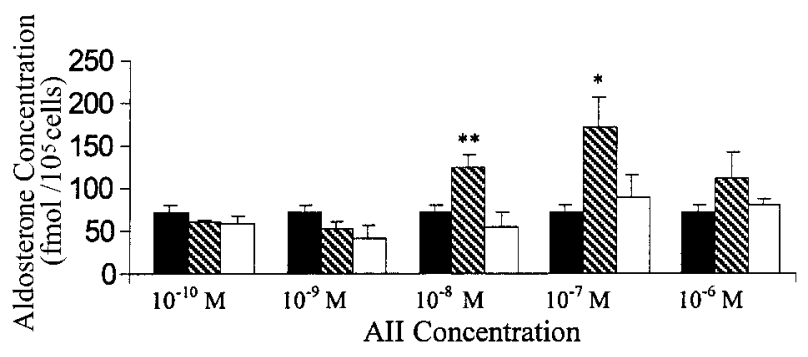

Figure 1 Aldosterone formation by RASMCs cultured for $48 \mathrm{~h}$ under different concentrations of All without (hatched bars) or with losartan $\left(10^{-5} \mathrm{M}\right)$ (open bars). Controls, solid bars. Values are means \pm S.E., $n=4$ per group. ${ }^{*} P<0 \cdot 05,{ }^{* *} P 0 \cdot 01$ versus control. All significantly enhanced aldosterone formation at $10^{-8}$ and $10^{-7} \mathrm{M}$, but not in the presence of losartan.

Strand buffer $(250 \mathrm{mM}$ Tris- $\mathrm{HCl}, \mathrm{pH} 8 \cdot 3$ at room temperature, $375 \mathrm{mM} \mathrm{KCl}, 15 \mathrm{mM} \mathrm{MgCl}_{2}$ ), $2 \mu \mathrm{l} 0 \cdot 01 \mathrm{M}$ dithiothreitol (DTT), $1 \mu \mathrm{l} 10 \mathrm{mM}$ each of dATP, dGTP, $\mathrm{dCTP}$ and dTTP at neutral $\mathrm{pH}$ (Gibco), 25 pmol antisense primers for rat aldosterone synthase, $0 \cdot 5 \mu \mathrm{l}$ RNAse inhibitor $(10 \mathrm{U} / \mu \mathrm{l}$, Gibco), $1 \mu \mathrm{l}$ reverse transcriptase $(200 \mathrm{U} / \mu \mathrm{l}$, Gibco), and the volume made up to $20 \mu \mathrm{l}$ with water. This was incubated at $37^{\circ} \mathrm{C}$ for $1 \mathrm{~h}$. The synthesized cDNA was stored at $-20^{\circ} \mathrm{C}$ until use. The sequences of sense and antisense primers for rat aldosterone synthase (CYP11B2) were designed according to published sequences and were custom-made by Gibco. The sequences of sense and antisense primers for rat aldosterone synthase were $5^{\prime}$ GATATCTTCAAAAGAGAGG $3^{\prime}$ and $5^{\prime}$ TACTGTTCAGCTAATCACG respectively, corresponding to bases 186-204 and 436-454 (exon 1-2) of the cloned full-length sequence. After incubation for $3 \mathrm{~min}$ at $94{ }^{\circ} \mathrm{C}, 2 \mu \mathrm{l}$ of the single-stranded cDNA in the $20 \mu \mathrm{l}$ reaction mixture were amplified using 50 pmol each of sense and antisense primers and $1 \mu \mathrm{l}$ Taq DNA polymerase $(5 \mathrm{U} / \mu \mathrm{l})$ in $100 \mu \mathrm{l} 20 \mathrm{mM}$ Tris- $\mathrm{HCl}(\mathrm{pH} 8 \cdot 4), 50 \mathrm{mM}$ $\mathrm{KCl}, 1.5 \mathrm{mM} \mathrm{MgCl}_{2}$, with $0.2 \mathrm{mM}$ of each dNTP. The reactions were performed for $1 \mathrm{~min}$ at $95^{\circ} \mathrm{C}$ and $1 \mathrm{~min}$ at $60{ }^{\circ} \mathrm{C}$ for 40 cycles. The RT-PCR products in $20 \mu \mathrm{l}$ aliquots were electrophoresed on a 1.4\% agarose gel.

\section{Results}

Aldosterone assay

The effects of increasing concentrations of AII on the secretion of aldosterone by cultured RASMCs are presented in Fig. 1. AII added alone at $10^{-8}$ and $10^{-7} \mathrm{M}$ significantly enhanced aldosterone formation, but not in the presence of losartan.

\section{Tritiated thymidine incorporation}

Tritiated thymidine incorporation was also increased in the cells stimulated with AII alone at above $10^{-10} \mathrm{M}$, but 


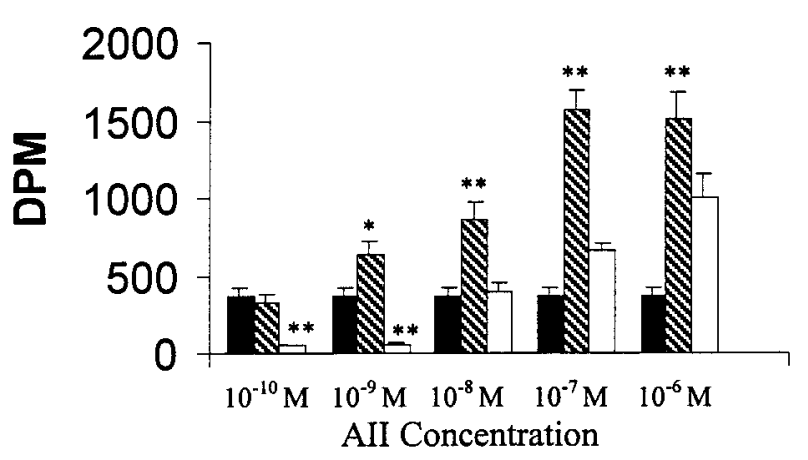

Figure $2\left[{ }^{3} \mathrm{H}\right]$ Methylthymidine incorporation to DNA in cultured RASMCs with different concentrations of All without (hatched bars) or with spironolactone $\left(10^{-5} \mathrm{M}\right.$ ) (open bars) for $48 \mathrm{~h}$. Controls, solid bars. Values are means \pm S.E, $n=4$ per group. Tritium incorporation was increased in the All-treated group above $10^{-9} \mathrm{M}$ but inhibited by spironolactone. Spironolactone also inhibited the $\left[{ }^{3} \mathrm{H}\right]$ thymidine uptake in the presence of non-stimulatory All concentrations $\left(10^{-10}\right){ }^{*} P<0 \cdot 05,{ }^{* *} P<0 \cdot 01$.

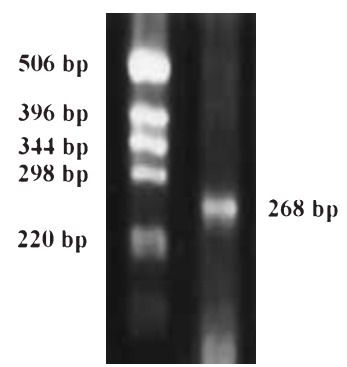

Figure 3 Using RASMC RNA and primers derived from the aldosterone synthase sequence, RT-PCR produced a single band, with the size predicted for aldosterone synthase of $268 \mathrm{bp}$.

this effect was inhibited in the presence of spironolactone (Fig. 2). Spironolactone also inhibited $\left[{ }^{3} \mathrm{H}\right]$ thymidine uptake in wells in which the concentration of AII $\left(10^{-10}\right)$ was not stimulatory.

\section{$R T-P C R$}

Using RASMC RNA and primers derived from the aldosterone synthase sequence, a single band was detected, with the size predicted for aldosterone synthase of $268 \mathrm{bp}$ (Fig. 3).

\section{Discussion}

There is an increasing body of evidence that locally produced vasoactive hormones that function on the autocrine-paracrine level (Dzau 1988) are important in cardiovascular regulation (Weber \& Brilla 1991, Baker et al. 1992). Thus, it has been shown that all components of the renin-angiotensin system (RAS) are expressed in both the vascular wall and the heart, and function in this way (Lokett \& Retallack 1970, Campbell 1977,
Dzau 1988, Paul et al. 1993). Extra-adrenal steroid 21-hydroxylation and 11 $\beta$-hydroxylation have also been shown to occur in a variety of human tissues (Takeda et al. 1994), and both messenger RNA coding for aldosterone synthase and also aldosterone synthesis have been reported in human endothelial cells and rat mesenteric arteries (Hatakeyama et al. 1994), although Gomez-Sanchez et al. (1997) were unable to confirm aldosterone formation in rat mesenteric artery. As in the adrenal, in which AII is an important regulator of adrenal mineralocorticoid biosynthesis and secretion (Aguilera et al. 1980, Shibata et al. 1991, Natarajan et al. 1992, Clyne et al. 1996, McEwan et al. 1996), the biosynthesis of aldosterone and corticosterone in rat cardiac muscle has also been shown to be stimulated by AII (Silvestre et al. 1998).

Since it is known that aldosterone may play a role in raising blood pressure by modulating human vascular smooth muscle tone (Pirpiris et al. 1992), the present study was undertaken to investigate the possibility that the proliferation of smooth muscle cells induced by AII may be mediated by aldosterone. The results do indeed show that AII enhanced aldosterone formation (Fig. 1). Since the AII-stimulated proliferation of these cells, as judged by tritiated thymidine uptake, was inhibited by spironolactone, the results further suggest that the action of AII is, at least partly, mediated by aldosterone (Fig. 2), particularly since RT-PCR suggested the presence of aldosterone synthase mRNA in cultured RASMCs (Fig. 3). However, the action of AII on aldosterone output was biphasic, since it was unaffected at micromolar concentrations, although it was stimulated at lower concentrations. This was not well correlated with tritiated thymidine uptake which was, nevertheless, still stimulated by micromolar concentrations of AII (albeit at a somewhat lower level than that shown at $0 \cdot 1 \mu \mathrm{mol} / \mathrm{l}$ ) and inhibited by spironolactone. The fact that spironolactone also inhibited the $\left[{ }^{3} \mathrm{H}\right]$ thymidine uptake at non-stimulatory levels of AII suggests a basal level of steroid biosynthesis in these cells. That this is a mineralocorticoid receptor-mediated effect is strongly indicated by the reported specificity of spironolactone (McInnes \& Ramsay 1987), although it remains possible that other steroids or receptors may be involved, since spironolactone may act not only as a potent mineralocorticoid antagonist, but may also directly interfere with the biosynthesis of aldosterone and other corticosteroids in the adrenal cortex (Müller 1988).

Several questions remain unresolved by these findings. One point is to understand the way in which aldosterone synthesis is achieved and regulated in these cells. Thus, the finding of aldosterone synthase alone is insufficient, given that, in the adrenal at least, a minimum of three cytochrome P-450 species and one dehydrogenase/isomerase system are required, i.e. CYP 11A (cholesterol side chain cleavage P450), $\Delta^{5}, 3 \beta$-hydroxysteroid dehydrogenase/ isomerase, CYP21 (21-hydroxylase) and CYP11B2 (aldosterone synthase). Furthermore, the regulation of 
aldosterone synthesis is thought to take place at two of these steps in biosynthesis, at least, namely at the point of cholesterol side chain cleavage and at a late pathway stage, presumably involving aldosterone synthase (Vinson et al. 1992). It will be necessary in the future to establish whether all these steps can occur locally within the vasculature, or whether there is a pool of precursor that is taken up from the circulation.

Clearly, too, the relative importance of circulating and locally synthesized aldosterone in normal physiology will have to be established. The field is currently digesting the now well documented significance of tissue located RASs, many of which appear to have physiological roles that are quite unrelated to those of the circulating system, including in particular reproductive functions (Vinson et al. 1995). In the vasculature, it is becoming evident that this is only part of the story.

\section{Acknowledgements}

F Xiao is in receipt of an ORS award.

\section{References}

Aguilera G \& Catt KJ 1983 Regulation of aldosterone secretion during altered sodium intake. Journal of Steroid Biochemistry 19 525-530.

Aguilera G, Menard RH \& Catt KJ 1980 Regulatory actions of angiotensin II on receptors and steroidogenic enzymes in adrenal glomerulosa cells. Endocrinology 107 55-60.

Baker KM, Booz GW \& Dostal DE 1992 Cardiac action of angiotensin II: role of an intracardiac renin-angiotensin system. Annual Review of Physiology 54 227-241.

Campbell DJ 1977 Circulating and tissue angiotensin system. Journal of Clinical Investigation 79 1-6.

Casey ML \& MacDonald PC 1982 Extra-adrenal formation of a mineralocorticosteroids-deoxycorticosterone and deoxycorticosterone sulfate biosynthesis and metabolism. Endocrine Reviews 3 396-403.

Clyne CD, White PC \& Rainey WE 1996 Calcium regulates human CYP11B2 transcription. Endocrine Research Communications 22 485-492.

Dzau VJ 1988 Circulation versus local renin-angiotensin system in cardiovascular homeostasis. Circulation 77 1-4.

Gomez-Sanchez EP 1991 What is the role of the central nervous system in mineralocorticoid hypertension? American Journal of Hypertension 4 374-381.

Gomez-Sanchez CE, Zhou MY, Cozza EN, Morita H, Foecking MF \& Gomez-Sanchez EP 1997 Aldosterone biosynthesis in the rat brain. Endocrinology 138 3369-3373.

Hatakeyama H, Miyamori I, Fujita T, Takeda Y, Takeda R \& Yamamoto H 1994 Vascular aldosterone - biosynthesis and a link to angiotensin II-induced hypertrophy of vascular smooth muscle cells. Journal of Biological Chemistry 269 24316-24320.

Hatakeyama H, Miyamori I, Takeda Y, Yamamoto H \& Mabuchi H 1996 The expression of steroidogenic enzyme genes in human vascular cells. Biochemistry and Molecular Biology International 40 639-645.

Henville KL, Hinson JP, Vinson GP \& Laird SM 1989 Actions of desacetyl-a-melanocyte-stimulating hormone on human adrenal cells. Journal of Endocrinology 121 579-583.

Lokett MF \& Retallack RW 1970 Factors controlling the secretion of a substance biologically resembling the 18-monoacetate of d-Aldo by heart muscle. Journal of Physiology 210 717-725.
McEwan PC, Lindop GB \& Kenyon CJ 1996 Control of cell proliferation in the rat adrenal gland in vivo by the renin-angiotensin system. American Journal of Physiology 34 E192-E198.

McInnes GT \& Ramsay LE 1987 Pharmacology and clinical uses of anti-mineralocorticoids. In Pharmacology and Clinical Uses of Inhibitors of Hormone Secretion and Action, pp 233-254. Eds BJA Furr \& AE Wakeling. London: Bailliere Tindall.

Mellon SH \& Deschepper CF 1993 Neurosteroid biosynthesis genes for adrenal steroidogenic enzymes are expressed in the brain. Brain Research 629 283-292.

Müller J 1988 Regulation of aldosterone biosynthesis. Monographs on Endocrinology, edn 2, pp 80-81. Berlin: Springer-Verlag.

Natarajan R, Gonzales N, Hornsby PJ \& Nadler J 1992 Mechanism of angiotensin II-induced proliferation in bovine adrenocortical cells. Endocrinology 131 1174-1180.

Ogishima T, Suzuki H, Hata JI, Mitani F \& Ishimura Y 1992 Zone specific expression of aldosterone synthase cytochrome P-450 and cytochrome P-45011 $\beta$ in rat adrenal cortex: histochemical basis for the functional zonation. Endocrinology 130 2971-2977.

Oikawa SI, Hori S, Sano R, Suzuki N, Fujii Y, Abe R \& Goto Y 1987 Effect of low density lipoprotein on DNA synthesis of cultured human arterial SMC. Atherosclerosis 64 7-12.

Paul M, Wagner J \& Dzau VJ 1993 Gene expression of the reninangiotensin system in human tissue. Journal of Clinical Investigation 91 2058-2064.

Pirpiris M, Sudhir K, Yeung S, Jennings G \& Whitworth JA 1992 Pressor responsiveness in corticosteroid-induced hypertension in humans. Hypertension 19 567-574.

Rubattu S, Enea I, Ganten D, Salvatore D, Condorelli G, Russo R, Romano M, Gigante B, Trimarco B \& Volpe M 1994 Enhanced adrenal renin and aldosterone biosynthesis during sodium restriction in TGR (mRNA2)27. American Journal of Physiology 30 E515-E520.

Ross R 1971 Growth of smooth muscle in culture and formation of elastic fibers. Journal of Cell Biology 50 172-186.

Shibata H, Ogishima T, Mitani F, Suzuki H, Murukami M, Saruta T \& Ishimura Y 1991 Regulation of aldosterone synthase cytochromep-450 in rat adrenals by angiotensin-II and potassium. Endocrinology 128 2534-2539.

Silvestre J-S, Robert V, Heymes C, Aupetit-Faisant B, Mouas C, Moalic J-M, Swynghedauw B \& Delcayre C 1998 Myocardial production of aldosterone and corticosterone in the rat. Journal of Biological Chemistry 273 4883-4891.

Takeda Y, Miyamori I, Yoneda T, Iki K, Hatakeyama H, Blair IA, Hsieh F-Y \& Takeda R 1994 Synthesis of corticosterone in the vascular wall. Endocrinology 135 2283-2286.

Takeda Y, Miyamori I, Yoneda T, Iki K, Hatakeyama H, Blair IA, Hsieh FY \& Takeda R 1995 Production of aldosterone in isolated rat blood vessels. Hypertension 25 170-173.

Takeda Y, Miyamori I, Yoneda T, Hatakeyama H, Inaba S, Furukawa K, Mabuchi H \& Takeda R 1996 Regulation of aldosterone synthase in human vascular endothelial cells by angiotensin II and adrenocorticotropin. Journal of Clinical Endocrinology and Metabolism 81 2797-2800.

Vinson GP, Whitehouse BJ \& Hinson JP 1992 The Adrenal Cortex. Englewood Cliffs: Prentice-Hall.

Vinson GP, Ho MM \& Puddefoot JR 1995 The distribution of angiotensin II type 1 receptors, and the tissue renin-angiotensin systems. Molecular Medicine Today 1 35-39.

Weber KT \& Brilla CG 1991 Pathological hypertrophy and cardiac interstitium: fibrosis and renin-angiotensin-aldosterone system. Circulation 83 1849-1865.

Received 21 June 1999

Revised manuscript received 26 November 1999 Accepted 30 December 1999 